\title{
Short communication: Effect of conjugated linoleic acid on concentrations of fat-soluble vitamins in milk of lactating ewes
}

\author{
J. O. Zeitz, ${ }^{1}$ E. Most, and K. Eder \\ University of Giessen, Institute of Animal Nutrition and Nutritional Physiology, Heinrich-Buff-Ring 26-32 (IFZ), D-35392 Giessen, Germany
}

\begin{abstract}
Conjugated linoleic acids (CLA) are well known as milk fat-reducing feed supplements in diets for lactating ruminants. However, their effects on milk concentrations of fat-soluble vitamins are unknown. This study was performed to investigate the hypothesis that CLA affect the concentrations of retinol and tocopherol in ewe milk. For that purpose, group-housed Merino ewes $(101 \pm 13.7 \mathrm{~kg})$ nursing twin lambs and fed with a hay:concentrate diet were supplemented with either 45 $\mathrm{g}$ of a rumen-protected CLA supplement containing 3.4 $\mathrm{g}$ of cis-9,trans-11-CLA and $3.4 \mathrm{~g}$ of trans-10,cis-12CLA (CLA group, $\mathrm{n}=11$ ) or with $45 \mathrm{~g}$ of a hydrogenated vegetable fat (control group, $\mathrm{n}=12$ ) per ewe per day during the first 6 wk of lactation. Feed intake was recorded daily (concentrate) or weekly (hay) per group. Milk spot samples were collected at the beginning of the experiment ( $5 \pm 2.4 \mathrm{~d}$ postpartum) and then weekly after lambs had been separated for $2 \mathrm{~h}$ from their mothers. The milk fat content was determined and feed and milk were analyzed for concentrations of $\alpha-, \gamma-$, and $\delta$-tocopherol and for retinol by HPLC. Dietary intake of tocopherol and retinol was similar in both groups. Feeding CLA decreased milk fat concentration by $23 \%$ on average, and during the first $3 \mathrm{wk}$ of the study milk tocopherol concentration tended to be increased by feeding CLA $(+17 \%)$, but retinol concentrations were not influenced. When related to milk fat, CLA feeding significantly increased both milk tocopherol $(+40 \%)$ and retinol $(+32 \%)$ and these effects were evident during the whole experimental period corresponding to the first half of lactation.
\end{abstract}

Key words: conjugated linoleic acid, milk fat-soluble vitamin, lactating ewe

\footnotetext{
Received December 10, 2014.

Accepted June 19, 2015.

${ }^{1}$ Corresponding author: Johanna.O.Zeitz@ernaehrung.uni-giessen.
} de

\section{Short Communication}

Conjugated linoleic acids are positional and geometric isomers of linoleic acid that are naturally occurring in ruminant-derived foods. Dietary CLA supplements, usually a mixture of the trans-10,cis-12 and the cis9,trans-11 isomer, have been shown to influence lipid metabolism in a range of species including lactating dairy cows (Baumgard et al., 2002; Schlegel et al., 2012a) and ewes (Hussein et al., 2013). In both ruminants and monogastric animals, supplementing CLA in the diet inhibits lipid synthesis by downregulating expression of several genes involved in lipid synthesis in muscle, adipose tissue, liver (Ringseis et al., 2004; Tous et al., 2012), and mammary gland (Baumgard et al., 2002; Gutgesell et al., 2009). Additionally, CLA inhibits lipoprotein lipase (LPL), which is crucial for lipid uptake from chylomicrons and very low density lipoproteins into tissues including the mammary gland (Ringseis et al., 2004; Hussein et al., 2013). Consequently, milk fat concentration is reduced and the FA composition is altered in lactating animals (Baumgard et al., 2002; Ringseis et al., 2004; Lock et al., 2006). In addition to the known effects on lipid metabolism, the metabolism of fat-soluble vitamins might be modified as well due to the fact that the metabolism of lipids and lipid-soluble vitamins are partly interlinked (Lemaire-Ewing et al., 2010; D'Ambrosio et al., 2011). Both vitamin A and E need to be emulsified by bile acids in the intestine and are transported in chylomicrons and lipoproteins together with other lipids (Lemaire-Ewing et al., 2010; D'Ambrosio et al., 2011). Distribution and metabolism of $\alpha$-tocopherol is closely related to that of other lipids transported in plasma lipoproteins, and LPL is also important for vitamin E uptake into extra-hepatic tissues (Lemaire-Ewing et al., 2010). Likewise, LPL plays a role in tissue uptake of retinol from chylomicrons, and enzymes and proteins that are involved in triglyceride and cholesterol metabolism are also involved in retinoid metabolism (D'Ambrosio et al., 2011).

Due to the described links between metabolism of lipids and vitamin $\mathrm{E}$ and $\mathrm{A}$, we hypothesized that supplementing CLA to the diet influences tocopherol and 
retinol concentrations in milk of lactating ewes both absolutely and in relation to milk fat. To investigate this hypothesis, a 42-d experiment was conducted at the Research Station of the Institute of Animal Breeding and Genetics at the University of Giessen, Germany. A total of 23 Merino ewes nursing twin lambs kept in a barn with loose straw bedding were randomly allocated to a treatment group (CLA; $\mathrm{n}=11$ ) and a control group (control, $\mathrm{n}=12$ ) based on day postpartum ( \pm 2.4 ; mean $\pm \mathrm{SD} ; P=0.34$ between groups), average $\mathrm{BW}$ $(101 \pm 13.7 \mathrm{~kg} ; P=0.92)$, and number of parity $(2.7 \pm$ $1.29 ; P=0.91)$. Ewes were group-housed together with their lambs and had free access to grass hay from a natural grassland (false oat-grass community type) and water ad libitum. Once daily, $1.5 \mathrm{~kg}$ per ewe per day of a commercial concentrate (RWZ Schaf 18 Uni Press, RWZ, Köln, Germany) was fed, which consisted of (g/ $\mathrm{kg}$ ): wheat bran (250), barley (200), rapeseed extraction meal (160), wheat gluten (100), beet pulp (100), dried distillers grains with solubles (44), corn (36), sunflower extraction meal (30), vinasse (30), calcium carbonate (26.7), sugar beet molasses (16), sodium chloride (1.3), magnesium oxide (3), and supplied vitamins and trace elements (per $\mathrm{kg}$ ): vitamin $\mathrm{A}, 8,000 \mathrm{IU}$; vitamin $\mathrm{D}_{3}$, 1,000 IU; vitamin E, $65 \mathrm{mg}$; zinc, $40 \mathrm{mg}$ as zinc sulfate monohydrate; manganese, $20 \mathrm{mg}$ as manganese (II) sulfate monohydrate; selenium, $0.2 \mathrm{mg}$ as sodium selenite; cobalt, $0.2 \mathrm{mg}$ as cobalt (II) sulfate monohydrate; and iodine, $0.1 \mathrm{mg}$ as calcium iodate. According to the supplier, the concentrate contained 10.6 MJ of ME $/ \mathrm{kg}$ and $180 \mathrm{~g} / \mathrm{kg}$ of CP. The concentrate was supplemented either with $30 \mathrm{~g} / \mathrm{kg}$ of a hydrogenated vegetable fat (control group; Sila R.r.l., Noale, Italy) or with the rumen-protected CLA supplement Lutrell (CLA group; BASF, Ludwigshafen, Germany). A saturated fat was chosen as the control fat to exclude biohydrogenation and the generation of unknown trans-FA and CLA isomers in the rumen. From the start of the experiment (i.e., approximately their 5th day of life), lambs had additional ad libitum access to a commercial concentrate (RWZ Schaf 18 Uni Press). Feed intake of hay per group was estimated based on average bale weight (6.8 $\pm 1.42 \mathrm{~kg}$; mean $\pm \mathrm{SD}$ ) and number of hay bales consumed weekly. Feed samples were collected weekly and were stored at $-20^{\circ} \mathrm{C}$ until analysis of a pooled sample according to the official German VDLUFA methodology (Bassler and Buchholz, 1993) for DM (no. 4.2.1), crude ash (8.1), crude fat (5.1.1), crude fiber (6.1.1), and $\mathrm{CP}(\mathrm{N} \times 6.25$; $\mathrm{CN}$-Analysator vario $\mathrm{MAX} \mathrm{N} / \mathrm{CN}$, elementar Analysesysteme GmbH, Hanau, Germany; 4.1.1), and of FA composition and fat-soluble vitamin concentration. The BW of ewes and their lambs were recorded at the beginning and the end of the experi- ment. Milk spot samples were collected weekly after lambs had been separated from their mothers for $2 \mathrm{~h}$, but milk yield was not determined. The spot samples were collected from both mammary glands; the first few milliliters of milk were discarded, and afterward, 10 to $15 \mathrm{~mL}$ of milk were sampled. The milk was stored at $-20^{\circ} \mathrm{C}$ in aliquots for later analysis of concentrations of milk fat, milk FA, and fat-soluble vitamins.

For milk fat determination, the fat was extracted with HiP (hexane:isopropanol, 3:2, vol/vol; Hara and Radin, 1978) overnight, and after centrifugation at $1,000 \times g$ for 5 min at $15^{\circ} \mathrm{C}$ the upper fat-containing phase was quantitatively transferred to a dried and weighed test glass. The test glass was dried to constant weight at $105^{\circ} \mathrm{C}$ and reweighed. The weighed fat was related to the initial milk weight. The coefficient of variation of 1 sample analyzed 6 times was 1.54\%. Feed and milk FA were determined by gas chromatography according to Schlegel et al. (2012b). Concentrations of retinol and $\alpha_{-}, \gamma_{-}$, and $\delta$-tocopherols were determined in feed and milk by HPLC (L-7100, LaChrom, Merck-Hitachi, Darmstadt, Germany) with fluorescence detection as described for tocopherols in Gessner et al. (2013) and detected by fluorescence (Fluorescence Detector L-7480, LaChrom, Merck-Hitachi, retinol: excitation wavelength, $325 \mathrm{~nm}$, emission wavelength, $475 \mathrm{~nm}$; tocopherols: excitation wavelength, $295 \mathrm{~nm}$, emission wavelength, $325 \mathrm{~nm}$ ). The $\delta$ - und $\beta$-tocopherol could not be separated and are summarized as $\delta$-tocopherol. Tocopherol equivalents were calculated using the naturally occurring stereoisomer of $\alpha$-tocopherol, RRR $\alpha$-tocopherol, as a reference $(R R R \alpha$-tocopherol $=1$; from now on called tocopherol) and $\gamma$-tocopherol was multiplied by 0.25 and $\delta$-tocopherol by 0.01 to consider the lower vitamin activity of those 2 tocopherol isomers (www.dge.de). $\beta$-Carotene was extracted in feed samples $(0.25 \mathrm{~g})$ using the same procedure, but separated on a LiChroCART DIOL 125-4 column (Merck, Schwalbach, Germany) with hexane as the mobile phase at a flow rate of 1 $\mathrm{mL} / \mathrm{min}$ and a pressure of 23 bar at $30^{\circ} \mathrm{C}$ and detected at $455 \mathrm{~nm}$ using a UV-VIS detector L4250 (Merck).

Data were statistically analyzed using the software $\mathrm{R}$ version 3.1.1 (R Development Core Team, 2011). For analysis of BW data, treatment was considered as fixed and animal as random effect and the function lme, package nlme, was used. Milk fat data were monitored over time, analyzed using treatment and the interaction between treatment and time as fixed effect, animal as random effect, and separate intercepts to account for the initial differences in milk fat content using lme. Milk vitamin and milk FA data were monitored over time as well, and the model included treatment and time and their interaction as fixed effects and animal 
Table 1. Fatty acid composition of the dietary components ( $\mathrm{g} / 100 \mathrm{~g}$ of FA analyzed)

\begin{tabular}{|c|c|c|c|c|}
\hline Fatty acid & CLA concentrate & Control concentrate & Lutrell $^{1}$ & Control fat \\
\hline$\overline{\mathrm{C} 12: 0}$ & $\mathrm{ND}^{2}$ & ND & 0.32 & 7.11 \\
\hline C14:0 & ND & ND & 0.32 & 3.46 \\
\hline C16:0 & 13.5 & 17.8 & 6.89 & 30.1 \\
\hline C18:0 & 8.12 & 8.87 & 12.28 & 47.9 \\
\hline C18:1n-9 & 24.0 & 21.7 & 29.0 & 9.39 \\
\hline $\mathrm{C} 18: 1 \mathrm{n}-7$ & 2.35 & 2.66 & ND & $\mathrm{ND}$ \\
\hline C18:2n-6 & 34.1 & 45.2 & 1.4 & 2.07 \\
\hline C18:3n-3 & 3.10 & 3.78 & ND & ND \\
\hline C18:2 cis- 9, trans -11 & 7.39 & ND & 25.0 & ND \\
\hline $\mathrm{C} 18: 2$ trans -10, cis -12 & 7.41 & ND & 24.8 & ND \\
\hline
\end{tabular}

${ }^{1}$ Lutrell (BASF, Ludwigshafen, Germany) = rumen-protected CLA supplement.

${ }^{2} \mathrm{ND}=$ below detection limit $(0.02 \mathrm{~g} / 100 \mathrm{~g}$ of FA).

as random effect using lmer; pairwise comparisons were done using the Hochberg test and the function lsmeans.

The nutrient composition of the feed was $(\mathrm{g} / \mathrm{kg}$ of DM): DM, 911, 854, 862; crude ash, 68.0, 79.3, 71.5; crude fat, not analyzed, 58.5, 65.0; and CP, 90.3, 203, 200 for hay, CLA concentrate, and control concentrate, respectively. The differences in crude nutrient concentration between the 2 experimental concentrates can be explained by the high crude ash content of the CLA product Lutrell $(199 \mathrm{~g} / \mathrm{kg})$. Crude fiber of hay was 341 $\mathrm{g} / \mathrm{kg}$ of DM. Vitamin concentration in the concentrates was as follows (mg/kg of DM): retinol, 1.25 and 1.23; total tocopherol, 64.6 and $66.3 ; \beta$-carotene, 0.76 and 0.75 in the CLA and the control concentrate, respectively. In hay, tocopherol concentration was $9.74 \mathrm{mg} / \mathrm{kg}$ of DM and retinol and $\beta$-carotene were below detection limit, which is markedly lower than the concentrations usually reported (Shingfield et al., 2005). In milk, $\beta$-carotene was below the detection limit as well $(<0.02$ $\mu \mathrm{g} / \mathrm{g}$ of milk). The FA composition of the fat supplements and of the control and CLA concentrates including fat supplements is shown in Table 1. Pelletizing had no influence on the FA composition of the concentrate (data not shown). The concentrate offered was always consumed completely, and the calculated daily intake of trans-10,cis-12-CLA from the concentrate was $3.41 \mathrm{~g}$ per ewe per day in the CLA group. The estimated intake of hay in experimental wk 1, 2, and 3 to 6 was 2.2 , 2.3 , and $2.8 \mathrm{~kg}$ of hay fresh matter per ewe per day on both treatment groups. Lambs had access to the same hay but were not considered for calculating hay intake of the ewes. Due to similar feed vitamin concentrations and feed intake between the experimental groups, the calculated daily intakes of fat-soluble vitamins for both groups were similar as well. Intake (mg per ewe per day) of retinol was 1.87 and 1.85 and intake of $\beta$-carotene was 1.14 and 1.12 during the whole experimental period for the CLA and the control group, respectively. Intake of hay and thus also of tocopherol increased with time.
Tocopherol intake (mg per ewe per day) in wk 1, 2, and 3 to 6 was 121 and 123, 121 and 124, and 127 and 130 for the CLA and the control group, respectively. Body weights of ewes were similar between treatment groups at the beginning $(101 \pm 13.7 \mathrm{~kg} ; P=0.92)$ and at the end $(98 \pm 10.2 \mathrm{~kg} ; P=0.26)$ of the experimental period. Lambs increased their BW from on average 5.9 $\pm 0.87 \mathrm{~kg}(P=0.78)$ to on average $22.6 \pm 4.43 \mathrm{~kg}(P=$ $0.35)$ both in the control and the CLA group. Average daily weight gain of lambs was similar in the control group (378 \pm 19.7$)$ and in the CLA group $(347 \pm 14.2$; $P=0.12)$.

The milk fat percentage decreased significantly, by $23 \%$ on average, in response to feeding the rumenprotected CLA supplement (Figure 1). The magnitude of this effect was comparable with that reported from others. For example, when 2.4 to $6.1 \mathrm{~g}$ of trans-10, cis12-CLA per $100 \mathrm{~kg}$ of BW and day were fed to ewes, the reported reductions in milk fat percentage were between 15 and 34\% (Lock et al., 2006; Sinclair et al., 2010). In the present study, the composition of milk FA was altered as well. As expected, in the CLA group, the proportion of the trans-10,cis-12-CLA of total milk FA was 2- to 3-fold higher than in the control group (Table 2). Additionally, the proportion of FA with more than $16 \mathrm{C}$ atoms increased and that of $\mathrm{FA}$ with less than $16 \mathrm{C}$ atoms decreased in the CLA group compared with the control group. This finding is consistent with the observation that the expression of genes involved in mammary lipid synthesis is reduced by CLA supplementation (Hussein et al., 2013). It is well known that the trans-10,cis-12-CLA isomer is responsible for the milk fat depression and the molecular mechanisms are well established (Baumgard et al., 2002; Bauman et al., 2008; Hussein et al., 2013). However, potential effects of CLA on fat-soluble vitamins are not well known although similarities in absorption and metabolism of lipids and lipid-soluble vitamins exist. We hypothesized that the changes in lipid metabolism are accompanied 


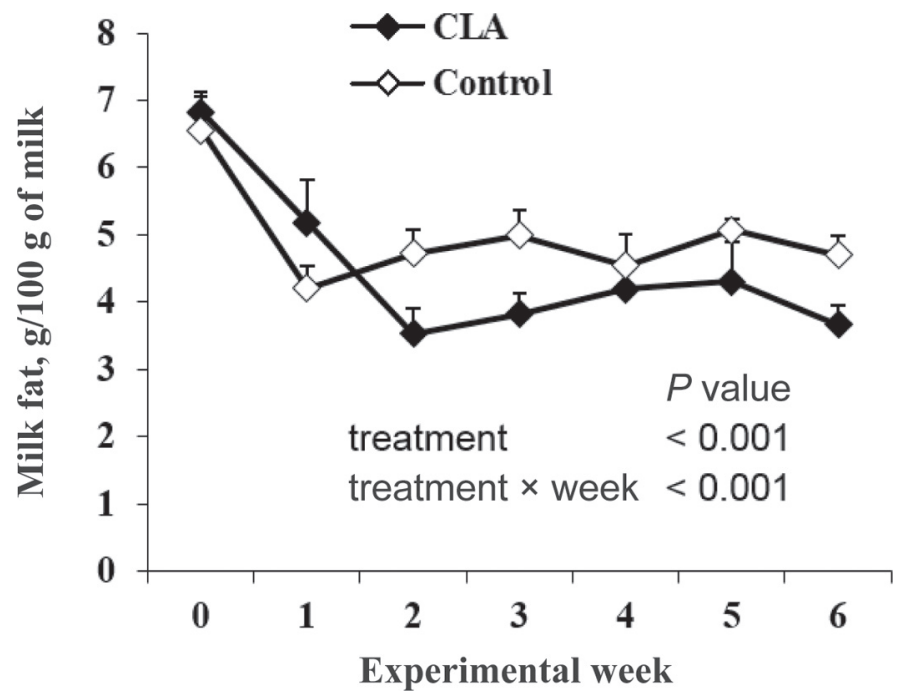

Figure 1. Milk fat concentration in ewes fed a CLA-containing concentrate as compared with a control concentrate (mean $\pm \mathrm{SE} ; \mathrm{n}$ $=11$ to 12$)$.

by changes in the metabolism of fat-soluble vitamins in ruminants. Studies performed in mice (Ortiz et al., 2009; Chao et al., 2010; Chen et al., 2012) and pigs (Dugan et al., 2002) indicate that vitamin E and A concentrations in liver and body tissues are enhanced upon CLA feeding. Tocopherol concentrations in muscle of heifers have been also enhanced after feeding a rumenprotected CLA supplement (Schlegel et al., 2012b). We show here that milk retinol concentrations were maintained and milk tocopherol concentrations in tendency enhanced despite reduced milk fat content in the CLAfed ewes (Figures $2 \mathrm{~A}$ and $2 \mathrm{C}$ ). In general, the milk concentrations of retinol and tocopherol were slightly lower or lower than those reported by others in mature ewe milk (Capper et al., 2005; Park et al., 2007; Gentili et al., 2013), which can be explained by their relatively low concentrations in the diet in the present study. Our study has 2 potential drawbacks due to technical reasons. Due to the fact that the ewes were suckling lambs, we could not quantitatively measure milk yield and we could only collect milk spot samples. We cannot exclude deviations of fat and vitamin concentrations in the spot samples from those in the complete daily produced milk; however, we assume that they have been minimized by our collection method and, if present, are randomly distributed between the 2 experimental groups. Although we could not measure milk yield in the present study, milk yield is generally unaffected by CLA feeding (Bauman et al., 2008; Hussein et al., 2013 ) or sometimes increased by about $10 \%$ (Lock et al., 2006; Sinclair et al., 2010). This makes it probable that not only milk vitamin concentrations, but also the milk vitamin output, were maintained or increased in the present study. It should be noted that the main feed vitamin source in the present study was the mineral and

Table 2. Fatty acid composition of milk of ewes fed a CLA-containing concentrate as compared with a control concentrate (g/100 g of FA analyzed)

\begin{tabular}{|c|c|c|c|c|c|c|c|c|c|c|}
\hline \multirow[b]{2}{*}{ Fatty acid } & \multicolumn{2}{|c|}{ Wk 2} & \multicolumn{2}{|c|}{ Wk 4} & \multicolumn{2}{|c|}{ Wk 6} & \multirow[b]{2}{*}{$\mathrm{SE}$} & \multicolumn{3}{|c|}{$P$-value } \\
\hline & Control & CLA & Control & CLA & Control & CLA & & $\begin{array}{l}\text { Treatment } \\
\quad(\mathrm{T})\end{array}$ & $\begin{array}{l}\text { Week } \\
(\mathrm{W})\end{array}$ & $\mathrm{T} \times \mathrm{W}$ \\
\hline C12:0 & 5.13 & 3.81 & 5.53 & 3.58 & 6.50 & 3.50 & 0.264 & 0.014 & 0.022 & 0.001 \\
\hline C14:0 & 11.2 & 9.9 & 11.8 & 10.1 & 13.4 & 10.6 & 0.387 & 0.002 & 0.001 & 0.07 \\
\hline C15:0 & 1.07 & 1.10 & 1.18 & 1.30 & 1.33 & 1.43 & 0.038 & 0.15 & $<0.001$ & 0.405 \\
\hline C15:1 & 0.30 & 0.33 & 0.31 & 0.38 & 0.36 & 0.42 & 0.010 & 0.002 & 0.002 & 0.42 \\
\hline $\mathrm{C} 17: 0$ & 1.09 & 1.10 & 1.06 & 1.03 & 1.02 & 1.08 & 0.030 & 0.72 & 0.083 & 0.20 \\
\hline $\mathrm{C} 17: 1$ & 0.60 & 0.62 & 0.60 & 0.59 & 0.56 & 0.55 & 0.018 & 0.89 & 0.030 & 0.84 \\
\hline C18:0 & 14.5 & 14.9 & 14.0 & 14.6 & 13.1 & 14.1 & 0.372 & 0.21 & 0.004 & 0.52 \\
\hline C18:1n-9 & 32.8 & 36.0 & 32.5 & 36.4 & 30.2 & 34.6 & 0.780 & 0.002 & 0.004 & 0.53 \\
\hline C18:2n-6 & 3.19 & 3.33 & 3.11 & 3.40 & 3.27 & 3.80 & 0.095 & 0.029 & 0.002 & 0.083 \\
\hline C18:3n-3 & 1.30 & 1.33 & 1.23 & 1.18 & 1.17 & 1.10 & 0.050 & 0.74 & 0.063 & 0.39 \\
\hline cis-9,trans-11-CLA & 0.95 & 1.15 & 0.97 & 1.21 & 0.90 & 1.15 & 0.036 & $<0.001$ & 0.037 & 0.58 \\
\hline \multicolumn{11}{|l|}{ Summation } \\
\hline$<\mathrm{C} 16$ & 17.7 & 15.2 & 18.9 & 15.4 & 21.6 & 16.0 & 0.649 & $<0.001$ & $<0.001$ & 0.011 \\
\hline$>\mathrm{C} 16$ & 55.4 & 59.5 & 54.5 & 59.6 & 51.3 & 57.7 & 0.871 & $<0.001$ & $<0.001$ & 0.22 \\
\hline
\end{tabular}



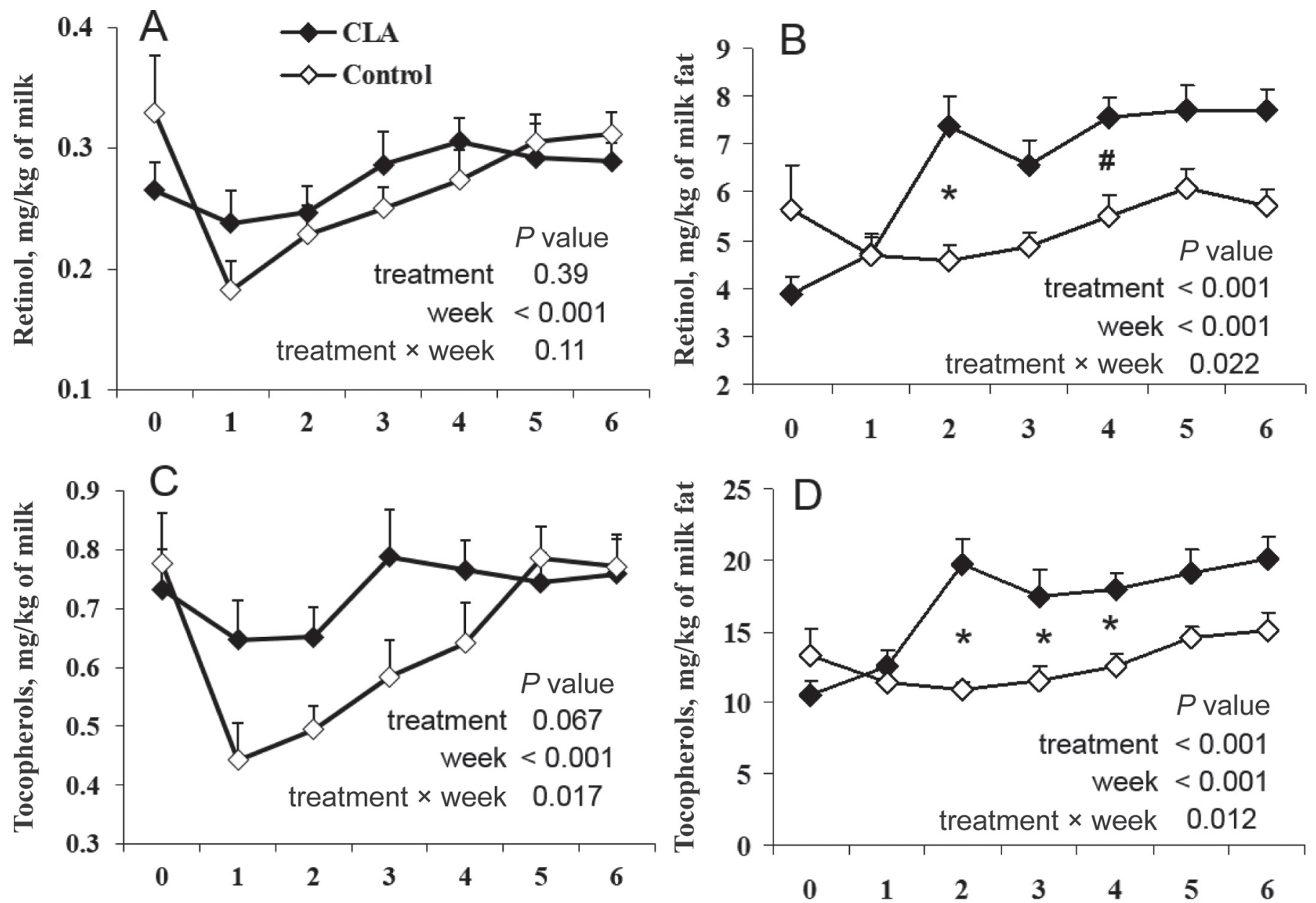

Experimental week

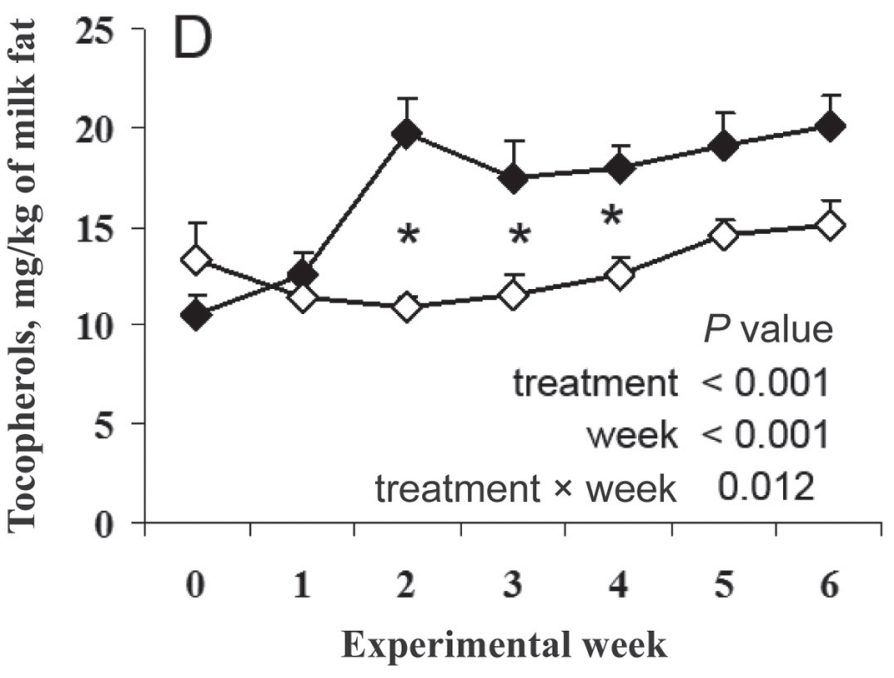

Figure 2. Concentrations of retinol (A), retinol related to milk fat (B), tocopherols (C), and tocopherols related to milk fat (D) in milk from ewes fed a CLA-containing concentrate as compared with a control concentrate (mean $\pm \mathrm{SE} ; \mathrm{n}=11$ to 12 ). $*$ indicates a difference at $P<0.05$ and \# indicates a difference at $P<0.1$ between groups within time point.

vitamin mix, which was identical in both experimental concentrates, and that the calculated vitamin intake was similar between groups; thus, changes in milk vitamin concentrations cannot be explained by differences in vitamin intake. When related to milk fat, feeding the rumen-protected CLA supplement resulted in enhanced concentrations of both retinol and tocopherol in milk (Figures $2 \mathrm{~B}$ and $2 \mathrm{D}$ ). The significant interaction between treatment and week in Figures 2B and 2D, which indicates that the CLA effect differs between weeks can be explained by the observation that the CLA effect was only evident from wk 2 on. However, we have no explanation for the observation that the effect of CLA seems to be reduced in wk 5 and 6 as compared with wk 2 to 4 (Figure 2). The enhanced vitamin concentrations when related to milk fat were unexpected because CLA feeding has been shown to reduce not only the gene expression of enzymes involved in mammary lipid synthesis, but also that of LPL, which is important for uptake of both FA (Baumgard et al., 2002; Hussein et al., 2013) and retinol and tocopherol (Lemaire-Ewing et al., 2010; D'Ambrosio et al., 2011). Our data therefore indicate that the uptake of vitamins into the mammary gland is not necessarily coupled to FA uptake. Tissue samples could not be obtained in the present study, and the underlying mechanisms for the observed effects on milk concentrations of fat-soluble vitamins have thus not been investigated. However, several studies have already shown that CLA influence liver vitamin $\mathrm{A}$ and $\mathrm{E}$ metabolism. The liver takes up chylomicron remnants from the bloodstream and synthesizes retinol binding protein (RBP) and $\alpha$-tocopherol transfer protein (TTP) for hepatic export and blood transport of retinol and tocopherol, respectively, the latter preferen- 
tially within very low density lipoproteins (Debier and Larondelle, 2005; Lemaire-Ewing et al., 2010; Berry et al., 2013). It has been shown in mice that TTP and its mRNA increased in liver and that serum tocopherol concentrations increased when feeding CLA (Chao et al., 2010; Chen et al., 2012). It can thus be speculated that, in CLA-fed animals, lipoproteins are enriched with $\alpha$-tocopherol. Also, tocopherol uptake from lipoproteins via scavenger receptor $\mathrm{BI}$ (SR-BI) and the low density lipoprotein (LDL) receptor (Lemaire-Ewing et al., 2010) may allow the mammary gland to maintain or even increase tocopherol uptake despite the decrease in LPL activity. This could explain why CLA feeding in the present study increased milk tocopherol concentrations in tendency and increased tocopherol significantly when related to milk fat. Similarly to TTP, RBP mRNA has been shown to increase in pig liver when feeding CLA (Dugan et al., 2002). Additionally, feeding the trans-10,cis-12-CLA isomer to mice increased liver retinol storage, liver retinol secretion, serum retinol and RBP levels, and adipose tissue retinyl esters (Ortiz et al., 2009). The mammary gland can incorporate retinoids from chylomicrons (via LPL) and from RBPbound retinol via specific receptors (O'Byrne et al., 2010; Alapatt et al., 2013; Li et al., 2014). Mammary gland uptake of RBP-bound retinol could be an explanation for the observation of the present study that milk retinol concentrations have been maintained in CLA-fed ewes despite the reduction in milk fat percentage. For example, it has been shown that mice lacking LPL were still able to incorporate retinol into milk via delivery of RBP-bound retinol and were able to maintain milk retinol concentrations (O'Byrne et al., 2010). In conclusion, we show that milk concentrations of fatsoluble vitamins were maintained or slightly enhanced in CLA-fed lactating ewes and were markedly enhanced when related to milk fat. The mechanisms responsible for the observed effects should be further investigated.

\section{REFERENCES}

Alapatt, P., F. Guo, S. M. Komanetsky, S. Wang, J. Cai, A. Sargsyan, R. E. Diaz, B. T. Bacon, P. Aryal, and T. E. Graham. 2013. Liver retinol transporter and receptor for serum retinol-binding protein (RBP4). J. Biol. Chem. 288:1250-1265.

Bassler, R., and H. Buchholz. 1993. Methodenbuch Band III. In Die Chemische Untersuchung von Futtermitteln, Ergänzungslieferung. 3rd ed. VDLUFA-Verlag, Darmstadt, Germany.

Bauman, D. E., J. W. Perfield, K. J. Harvatine, and L. H. Baumgard. 2008. Regulation of fat synthesis by conjugated linoleic acid: Lactation and the ruminant model. J. Nutr. 138:403-409.

Baumgard, L. H., E. Matitashvili, B. A. Corl, D. A. Dwyer, and D. E. Bauman. 2002. trans-10, cis-12 conjugated linoleic acid decreases lipogenic rates and expression of genes involved in milk lipid synthesis in dairy cows. J. Dairy Sci. 85:2155-2163.

Berry, D. C., H. Jacobs, G. Marwarha, A. Gely-Pernot, S. M. O'Byrne, D. DeSantis, M. Klopfenstein, B. Feret, C. Dennefeld, W. S. Blaner,
C. M. Croniger, M. Mark, N. Noy, and N. B. Glyselinck. 2013. The STRA6 receptor is essential for retinol-binding protein-induced insulin resistance but not for maintaining vitamin A homeostasis in tissues other than the eye. J. Biol. Chem. 288:24528-24539.

Capper, J. L., R. G. Wilkinson, E. Kasapidou, S. E. Pattinson, A. M. Mackenzie, and L. A. Sinclair. 2005. The effect of dietary vitamin $\mathrm{E}$ and fatty acid supplementation of pregnant and lactating ewes on placental and mammary transfer of vitamin $\mathrm{E}$ to the lamb. Br. J. Nutr. 93:549-557.

Chao, P.-M., W.-H. Chen, C.-H. Liao, and H.-M. Shaw. 2010. Conjugated linoleic acid causes a marked increase in liver alpha-tocopherol and liver alpha-tocopherol transfer protein in C57BL/6 J mice. Int. J. Vitam. Nutr. Res. 80:65-73.

Chen, W.-H., Y.-J. Li, M.-S. Wang, Z.-C. Kang, H.-L. Huang, and H.-M. Shaw. 2012. Elevation of tissue alpha-tocopherol levels by conjugated linoleic acid in C57BL/6J mice is not associated with changes in vitamin $\mathrm{E}$ absorption or alpha-carboxyethyl hydroxychroman production. Nutrition 28:59-66.

D'Ambrosio, D. N., R. D. Clugston, and W. S. Blaner. 2011. Vitamin A metabolism: An update. Nutrients 3:63-103.

Debier, C., and Y. Larondelle. 2005. Vitamins A and E: Metabolism, roles and transfer to offspring. Br. J. Nutr. 93:153-174.

Dugan, M. E. R., D. C. Rolland, D. R. Best, and W. J. Meadus. 2002. The effects of feeding conjugated linoleic acid on pig liver vitamin A and retinol binding protein mRNA. Can. J. Anim. Sci. 82:461-463.

Gentili, A., F. Caretti, S. Bellante, S. Ventura, S. Canepari, and R. Curini. 2013. Comprehensive profiling of carotenoids and fat-soluble vitamins in milk from different animal species by LC-DADMS/MS hyphenation. J. Agric. Food Chem. 61:1628-1639.

Gessner, K., A. Fiesel, E. Most, J. Dinges, G. Wen, R. Ringseis, and K. Eder. 2013. Supplementation of a grape seed and grape marc meal extract decreases activities of the oxidative stress-responsive transcription factors NF- $\kappa \mathrm{B}$ and Nrf2 in the duodenal mucosa of pigs. Acta Vet. Scand. 55:18-27.

Gutgesell, A., R. Ringseis, and K. Eder. 2009. Short communication: Dietary conjugated linoleic acid down-regulates fatty acid transporters in the mammary glands of lactating rats. J. Dairy Sci. 92:1169-1173.

Hara, A., and N. S. Radin. 1978. Lipid extraction of tissues with a low-toxicity solvent. Anal. Biochem. 90:420-426.

Hussein, M., K. H. Harvatine, W. M. P. B. Weerasinghe, L. A. Sinclair, and D. E. Bauman. 2013. Conjugated linoleic acid-induced milk fat depression in lactating ewes is accompanied by reduced expression of mammary genes involved in lipid synthesis. J. Dairy Sci. 96:3825-3834.

Lemaire-Ewing, S., C. Desrumaux, D. Neel, and L. Lagrost. 2010. Vitamin $\mathrm{E}$ transport, membrane incorporation and cell metabolism: Is alpha-tocopherol in lipid rafts an oar in the lifeboat? Mol. Nutr. Food Res. 54:631-640.

Li, Y., N. Wongsiriroj, and W. S. Blaner. 2014. The multifaceted nature of retinoid transport and metabolism. Hepatobiliary Surg. Nutr. 3:126-139.

Lock, A. L., B. M. Teles, J. W. Perfield, D. E. Bauman, and L. A. Sinclair. 2006. A conjugated linoleic acid supplement containing trans-10, cis-12 reduces milk fat synthesis in lactating sheep. J. Dairy Sci. 89:1525-1532.

O'Byrne, S. M., Y. Kako, R. J. Deckelbaum, I. H. Hansen, K. Palczewski, I. J. Goldberg, and W. S. Blaner. 2010. Multiple pathways ensure retinoid delivery to milk: Studies in genetically modified mice. Am. J. Physiol. Endocrinol. Metab. 298:E862.

Ortiz, B., L. Wassef, E. Shabrova, L. Cordeddu, S. Banni, and L. Quadro. 2009. Hepatic retinol secretion and storage are altered by dietary CLA: Common and distinct actions of CLA c9,t11 and t10,c12 isomers. J. Lipid Res. 50:2278-2289.

Park, Y. W., M. Juarez, M. Ramos, and G. F. W. Haenlein. 2007. Physico-chemical characteristics of goat and sheep milk. Small Rumin. Res. 68:88-113.

R Development Core Team. 2011. R: A language and environment for statistical computing. R Foundation for statistical computing, Vienna, Austria. https://www.R-project.org/. 
Ringseis, R., D. Saal, A. Muller, H. Steinhart, and K. Eder. 2004. Dietary conjugated linoleic acids lower the triacylglycerol concentration in the milk of lactating rats and impair the growth and increase the mortality of their suckling pups. J. Nutr. 134:3327-3334.

Schlegel, G., R. Ringseis, M. Shibani, E. Most, M. Schuster, F. J. Schwarz, and K. Eder. 2012b. Influence of a rumen-protected conjugated linoleic acid mixture on carcass traits and meat quality in young Simmental heifers. J. Anim. Sci. 90:1532-1540.

Schlegel, G., R. Ringseis, W. Windisch, F. J. Schwarz, and K. Eder. 2012a. Effects of a rumen-protected mixture of conjugated linoleic acids on hepatic expression of genes involved in lipid metabolism in dairy cows. J. Dairy Sci. 95:3905-3918.

Shingfield, K. J., P. Salo-Väänen, E. Pahkala, V. Toivonen, S. Jaakkola, V. Piironen, and P. Huhtanen. 2005. Effect of forage conser- vation method, concentrate level and propylene glycol on the fatty acid composition and vitamin content of cows' milk. J. Dairy Res. 72:349-361.

Sinclair, L. A., M. P. B. Weerasinghe, R. C. Wilkinson, M. J. de Veth, and D. E. Bauman. 2010. A supplement containing trans-10, cis-12 conjugated linoleic acid reduces milk fat yield but does not alter organ weight or body fat deposition in lactating ewes. J. Nutr. 140:1949-1955.

Tous, N., P. K. Theil, C. Lauridsen, R. Lizardo, B. Vila, and E. Esteve-Garcia. 2012. Dietary conjugated linoleic acid modify gene expression in liver, muscles, and fat tissues of finishing pigs. J. Anim. Sci. 90:340-342. 